\title{
Japan's Role in Improving Global Economic Governance in the Era of US-China Strategic Competition
}

\author{
Masahiro Kawai
}

\begin{abstract}
This essay provides an analysis of global economic governance from a Japanese perspective. There is an analysis of the "rules based world order" in the context of changing trends, such as the relative decline of the US economy and a rapid rise of the Chinaese economy. The essay focuses on the state of global economic governance from the perspectives of international forums - such as the $G 7$ and the G20 - and international organizations such as the IMF, World Bank and the WTO It tackles key questions: Can the international community build a new rules-based, liberal, multilateral economic governance order? If so, what needs to be done and what role can Japan play as a strong supporter of such an order? How can Japan work with China for this purpose? The essay argues that Japan can play a major role in addressing such challenges. It also urges Japan to work with not only the US and the EU but also China and other major emerging economies in order to reform the WTO, and put it back on the center stage of global rule-making for twenty-first-century trade and investment.
\end{abstract}

Keywords Global economic governance from a Japanese perspective • Rules-based world order - Relative decline of the US - Rapid rise of the Chinese economy $\cdot$ State of global economic governance $\cdot$ G7 and G20 • The IMF • The World Bank and the WTO • Japan - China cooperation • Reform of the WTO

\section{Introduction}

COVID-19 has severely affected most economies in the world. For any return to sustained economic growth, a rules-based, liberal global economic order is vital. At the same time, US-China strategic competition has expanded from trade to technology, security, and state governance issues. So, it is unclear if, or how, the international community can deal with the urgent need to strengthen global economic governance.

\footnotetext{
M. Kawai (ه)

The Economic Research Institute for Northeast Asia, Niigata, Japan

University of Tokyo, Tokyo, Japan 
The administration in the US, under Joe Biden, is returning to multilateralism and global cooperation through the UN-led Paris Agreement on global warming; the World Health Organization (WHO); the UN Human Rights Council; the UN Educational, Scientific and Cultural Organization and possibly the UN Educational, Scientific and Cultural Organisation (UNESCO) the Iran. Whether the US under Biden will rejoin the Trans-Pacific Partnership (TPP) is not clear, but if it does, it may take a few years. The Biden administration continues to regard China as the "strategic competitor" of the US and describes China as the "most serious competitor" to the US. The Biden team has adopted a tough policy stance against China on issues including human rights, Hong Kong's autonomy, and Taiwan. In facing China, the Biden administration has been acting together with its allies, such as the EU, the UK, Japan, Australia, and Canada rather than acting alone. At the same time, Biden favors cooperating with China on common global issues such as climate change, anti-terrorism, cybersecurity, and arms control.

Given this background, this essay asks the following questions: What is the structure of the global economy that characterizes recent changes such as the relative decline of the US and a rapid rise of the Chinese economy? What is the state of global economic governance from the perspectives of international forums like the G7 and the G20, and international organizations like the International Monetary Fund (IMF), World Bank and the World Trade Organization (WTO)? Can the international community return to a rules-based, liberal, multilateral economic governance order, which has benefited many countries, including China and Japan enormously in the post-WWII period? If so, what needs to be done and what role can Japan play as a strong supporter of such an order? How can Japan work with China toward this goal?

\section{Structural Changes in the World Economy and the Evolution of the G20}

One of the most fundamental structural changes in the world economy over the last 30 years is the relative decline of the US and other advanced economies such as the G7 and the rapid rise of the Chinese and other emerging and developing economies such as the BRICS countries (Brazil, Russia, India, China, and South Africa). As a result, the latter economies have begun to demand a greater voice for global economic management. A core catalyst for this structural change was the 2007-09 global financial crisis (GFC), which led to the G20 assuming a leading role in navigating global economic recovery. 


\subsection{Structural Shift in the World Economy}

Emerging and developing economies had made their voices heard for rule-making in global economic governance well before the GFC. During negotiations for the WTO's Doha Development Round (DDR), they placed priorities on their own socio-economic development needs, which were different from those of advanced economies, thereby complicating global trade negotiations. They also wanted to have a greater voice in the IMF, but this took much longer to realize than expected. China launched the Belt and Road Initiative (BRI) and took leadership in 2016 in establishing the Asian Infrastructure Investment Bank (AIIB).

As an outcome of this structural change, particularly the rapid growth of the Chinese economy achieved since its accession to the WTO in 2001, the US has come to view China as having "exploit(ed) the free and open rules-based order" supported by the WTO, IMF, and the World Bank, as well as attempting to "reshape the international system in its favor" through the BRI and other related frameworks. ${ }^{1}$ The US has begun to view the rise of China's economic, technological, and military capabilities as a threat to its global hegemonic dominance.

Projecting world economic growth over the next 50 years or so, China's economy will continue to expand, exceeding the size of the US economy (measured by nominal GDP at market exchange rates) around 2030, and becoming by far the largest in the world by 2050. This is a major concern for the US and its allies.

However, the sum of the US and EU GDPs would remain larger than China's GDP for the next 50 years and beyond. This suggests that it would be in the interest of the US to work with the EU and other like-minded advanced democracies (such as Australia, Canada, Japan, and the UK), if it wanted to maintain economic dominance and national security against a rising China, as the US would remain the leader among these democracies. The Trump administration ignored and the Biden administration recognizes this fact. India will also grow rapidly and will likely work with Western democracies, making China's economic dominance even more difficult. The rise of China and India would also mean that the Indo-Pacific will be one of the most dynamic regions of the world.

Thus, for the US, cooperation with allies rather than the "America-first" approach is the way to assure global leadership and national security, as economic size is a key determinant of military capabilities. At the same time, if China achieves a peaceful, harmonious rise without major friction with the US and other advanced economies, and provides an increasing volume of genuine international public goods, the country can legitimately claim a greater voice in the high table of global economic governance.

\footnotetext{
${ }^{1}$ US National Security Council (2020) .
} 


\subsection{Evolution of the G20 Summit}

The G20 summit, upgraded from a process for finance ministers and central bank governors to that for leaders, played a crucial role to resolve the GFC. Each member of the G20 was identified as a "systemically significant economy" that should be at the G20 table to help overcome global economic challenges for the benefit of all. This meant a major shift in global economic governance from the $\mathrm{G} 7$ to a broader group, encompassing large emerging and developing economies, with not only greater voice but also greater responsibilities for global economic management.

The G20 leader process was needed because cooperation by the rising economic power of emerging and developing economies was considered essential to tackle the severe negative impact of the GFC, as the G7's ability to manage the GFC by themselves was limited. Indeed, emerging and developing economies grew much faster than the G7 economies and thus greatly contributed to world economic recovery.

For a few years after the 2008 Lehman shock, the G20 Summit focused on tackling the GFC jointly, strengthening the resource bases and functions of international financial institutions (particularly the IMF, the World Bank, and regional multilateral development banks), and stepping up financial sector regulation to avoid another financial crisis. The Summit was called "the premier forum for international economic cooperation" in Pittsburgh in September 2009. Once global economic recovery took hold, the summit shifted its focus to various macroeconomic, financial, structural, and developmental issues of global relevance, with support from major international organizations (such as the UN, IMF, World Bank, WTO, Organisation for Economic Co-operation and Development [OECD], and more recently WHO) as an integral part of global economic governance.

\section{The Bretton Woods System}

The Bretton Woods System (BWS $)^{2}$ played a critical role in supporting the rulesbased, liberal, multilateral economic order in the post-WWII era. The IMF and the World Bank, which had evolved from the Bretton Woods Conference, responded to the negative impact of the 2007-09 GFC and have been dealing with economic difficulties arising from the recent COVID-19 pandemic. The WTO complements the BWS by setting rules for, and promoting free, non-discriminatory and multilateral trade.

\footnotetext{
${ }^{2}$ See Sandra Kollen Ghizoni, "Creation of the Bretton Woods System," Federal Reserve History (November 22, 2013). https://www.federalreservehistory.org/essays/bretton-woods-created.
} 


\subsection{The IMF}

The IMF began significant reform to augment its crisis response capacity and streamline lending conditions after the Asian financial crisis of 1997-98. The IMF was required to respond to the GFC with a quota increase and adjustment of voting shares in favor of emerging and developing economies (agreed to in 2010 and implemented in 2016). The US is the largest shareholder in the IMF and holds veto power, followed by Japan, China, Germany, France, and the UK . Reflecting the rising importance of the Chinese yuan for global use, the currency was included in the Special Drawing Rights (SDR) basket in October 2016. However, the next quota increase, which would accompany voting power shifts, is not scheduled to take place until the end of 2023.

Facing the COVID-19 pandemic, the IMF, headed currently by Kristalina Georgieva, has responded to its negative impact with support for vulnerable developing countries. For example, it has provided emergency assistance to developing countries with high levels of debt, weak medical systems, and severely impacted commodity sectors. It has temporarily doubled the member countries' access to emergency facilities, such as the Rapid Credit Facility and Rapid Financing Instrument, without the need to have a full-fledged program in place. It has also extended debt service relief through the Catastrophe Containment and Relief Trust (CCRT) to 29 of its poorest and most vulnerable member countries to cover their IMF debt obligations falling due to the IMF for the period between April 2020 and April 2021. Adopting the joint proposal made by the IMF and the World Bank, the G20 countries agreed in April 2020 to suspend repayment of official bilateral credit from the 73 low and lower middle-income countries initially until the end of 2020 and later until the end of June 2021 under the Debt Service Suspension Initiative (DSSI). In November 2020, the G20 countries agreed on a framework of debt reduction for these developing countries, which the IMF supports together with the World Bank.

It is likely that more financial assistance will be needed for not only low and lower middle-income countries but also for emerging economies severely hit by the pandemic. The IMF has about USD 1 trillion available for new lending. Although this is sufficient at the moment, the institution has been exploring ways to expand resources to support its more vulnerable members. The proposed new allocation of SDRs - as much as USD 650 billion - to provide flexibility to countries with liquidity shortages, which had been opposed by the Trump administration, gained support from the Biden administration, on the condition that new resources should benefit those developing countries truly in need of support, and not countries like China. This new allocation of SDRs was finally approved by the IMF Governors in the summer of 2021. 


\subsection{The World Bank}

The World Bank has been transforming itself from an organization using a onesize-fits-all "Washington Consensus" 3 to one that respects members' ownership and country-driven institutional and governance reforms to improve the business climate. As in the case of the IMF, the US, Japan, China, Germany, France, and the UK are the top six shareholding members in the International Bank for Reconstruction and Development (IBRD), and these countries with the exception of China are the top five contributors to the International Development Association (IDA), with China being the tenth largest contributor.

The World Bank has maintained relatively good relations with China by supporting its economic reform and market opening, although most experts view these reforms to have stalled in recent years. The Bank has also cooperated with China on the BRI (Belt and Road Initiative) and jointly financed projects. Even though David Malpass, a China "hawk" and a critic of the BRI, assumed Bank presidency in April 2019, the Bank has not cut its lending to China drastically and has maintained joint projects with the AIIB.

In response to the COVID-19 pandemic, the World Bank announced in May 2020 that it would provide up to USD 160 billion to most of its developing member countries over the following 15 months through the Fast-Track Facility to address their health, economic, and social difficulties. This would include funding of USD 50 billion from IDA resources as grants and highly concessional loans. By February 2021, a total of 84 countries had benefited from the dedicated COVID-19 FastTrack Facility, and 87 countries (with overlap with the above) had been under other financing programs. ${ }^{4}$

The IMF and the World Bank have been fully backed by the US government, and even the Trump administration never criticized the IMF or the Bank. The reason for this is that the US is the number one shareholder for both institutions with veto power and that these sister institutions are located in Washington, DC. Although the managing director (MD) of the IMF has always been a European, the US has played a key role by ensuring that the first deputy MD is always an American. The president of the World Bank has always been an American.

\footnotetext{
${ }^{3}$ The "Washington Consensus" is a set of economic policies prescribed for developing countries by Washington, D.C.-based institutions such as the IMF, World Bank, and the US Treasury Department.

${ }^{4}$ See World Bank Group's Operational Response to COVID-19 (coronavirus) —Project List. https:// www.worldbank.org/en/about/what-we-do/brief/world-bank-group-operational-response-covid19-coronavirus-projects-list\#fasttrack.
} 


\subsection{The WTO (World Trade Organisation)}

The world trading system under the General Agreement on Tariffs and Trade (GATT), and the subsequent WTO, worked well until the turn of the millennium. ${ }^{5}$ The WTO has faced the most serious challenges as its function has been severely damaged in recent years.

The WTO, established in 1995, was expected to strengthen the global trading system by stepping up existing trade rules, introducing new rules, and upgrading the dispute settlement procedure. China's accession to the WTO in December 2001 was considered a boost to global trade and investment. However, the failure of the DDR to deliver comprehensive agreements and the Trump administration's engagement in a US-China trade war in 2018-19 have put the WTO in a crisis situation in all of its three functions: providing a forum to negotiate new trade rules; monitoring members' trade policies; and resolving trade disputes among members.

It is difficult for the WTO's diverse members to reach agreements on further trade liberalization, new trade rules, and changes in member obligations because such agreements require full consensus among them. This was evident in DDR (Doha Development Round) negotiations, where the interests of developed and developing members collided and, as a result, comprehensive agreements were not reached.

Many developing countries, including China and India, have not complied with notification and transparency obligations with regard to changes in such trade policies as subsidies and regulations. Although the US, the EU, and Japan have called for new rules that would penalize members for not complying with their notification obligations, ${ }^{6}$ it is unlikely that such rules would be agreed upon by all members, especially developing countries.

In addition, the US has long criticized the function of the Appellate Body (AB), a standing body that can uphold, modify, or reverse the legal findings and conclusions of a panel after hearing appeals brought by WTO members, for its excessively interpretative decisions and overreach. ${ }^{7}$ There is a major philosophical difference between the US and the EU on the role of the dispute settlement mechanism. The issue is whether it is permissible for the AB to articulate rules and develop a set of international common laws without the consensus of all members. ${ }^{8}$ The EU supports this idea while the US rejects it. The US has claimed that the AB has repeatedly exercised its authority beyond its original mandate by reinterpreting WTO agreements and has treated $\mathrm{AB}$ reports as precedent against the Dispute Settlement Understanding. As

\footnotetext{
${ }^{5}$ See VanGrassteck (2013).

${ }^{6}$ WTO General Council, "Procedures to Enhance Transparency and Strengthen Notification Requirements under WTO Agreements." Communication from Argentina, Australia, Canada, Costa Rica, the European Union, Israel, Japan, New Zealand, Taiwan, United Kingdom, and the United States, JOB/GC/204/Rev.4, JOB/CTG/14/Rev.4 (24 November 2020). www.wto.org.

${ }^{7}$ The Office of the United States Trade Representative, 2020 Trade Policy Agenda and 2019 Annual Report (February 2020). https://ustr.gov/sites/default/files/2020_Trade_Policy_Agenda_ and_2019_Annual_Report.pdf.

${ }^{8}$ Willems (2020).
} 
a result, the US government, since the Barack Obama administration, has blocked new appointments of judges to fill vacancies and refused their reappointments after their terms, eventually leaving the AB with only one judge in December 2019. With a minimum of three judges required for it to function, the WTO has become unable to fully resolve trade disputes among members.

Furthermore, the US government has had bipartisan concerns over China's "nonmarket" policies and practices, forced technology transfers, its "developing country" status, and the special and differential (S\&D) treatment enjoyed by China. The US, together with the EU and Japan, has argued that "non-market-oriented" policies and practices, as well as forced technology transfers, have created unfair competitive advantages and undermined the proper functioning of international trade. ${ }^{9}$ The US has urged "non-market" economies, such as China, to move toward greater market openness and competition by reforming state-owned enterprises (SOEs) and eliminating state subsidies. The US has also argued that entitlement to S\&D treatment should not be granted to countries classified as "high income" by the World Bank, OECD members or its acceding ones, G20 members, or any country accounting for $0.5 \%$ or more of world trade. ${ }^{10}$

The new Director-General of WTO, Ngozi Okonjo-Iweala, faces daunting challenges as, under the consensus requirement, these fundamental reforms are unlikely to be achieved soon, even though most members believe some reform is necessary.

\section{Japan's Approach}

Japan strongly supports the IMF, the World Bank and the WTO because she has benefited enormously from a rules-based liberal international economic order. Japan delivered productive outcomes at the Osaka G20 summit in June $2019^{11}$ and is now pushing forward the Free and Open Indo-Pacific (FOIP) vision to forge trade in the region that is rules-based, free, and open, and designed to have positive implications for global economic governance. At the same time, Japan has been working with China with a view to encouraging it to be a responsible player in the global community.

\footnotetext{
${ }^{9}$ See the joint statements by the trade ministers of Japan, the US, and the EU, particularly from the 4th (September 2018) through the 7th trilateral meeting (January 2020). The most recent statement is available from: https://www.meti.go.jp/press/2019/01/20200114007/20200114007-2.pdf.

${ }^{10}$ WTO General Council, "Draft General Council Decision: Procedures to Strengthen the Negotiating Function of the WTO." Communication circulated at the request of the delegation of the United States, WT/GC/W/764/Rev.1 (November 25, 2019). https://www.mofa.go.jp/policy/economy/g20_ summit/osaka19/en/documents/final_g20_osaka_leaders_declaration.html.

${ }^{11}$ The most recent G20 summit was held in Riyadh, Saudi Arabia in November 2020, which was limited to a virtual meeting due to the COVID-19 pandemic.
} 


\subsection{Japan's Presidency of the Osaka G20 Summit}

The Osaka G20 summit in June 2019 was a big success for Japan, assisted by ministerial processes, particularly by ministers of finance, foreign, trade, digital, and economics along with central bank governors. ${ }^{12}$ All provided key inputs to the G20 leaders.

On the trade and investment agenda, the G20 leaders strove to realize a free, fair, non-discriminatory, transparent, predictable, and stable trade and investment environment, and to keep their markets open. In addition, they supported necessary reforms of the WTO and recognized the complementary roles of bilateral and regional free trade agreements (FTAs) that are WTO-consistent. During this period, when the WTO had become severely dysfunctional, it was considered important for economies to explore trade and investment liberalization and new rule-making through bilateral and regional FTAs.

Japan indeed has been promoting regional trade and investment through two megaregional FTAs, namely the Comprehensive and Progressive Agreement for TransPacific Partnership (CPTPP), which took effect in December 2018, and the Regional Comprehensive Economic Partnership (RCEP), which was signed in November 2020. Japan supports the vision to forge a Free Trade Area in the Asia-Pacific region among Asia-Pacific Economic Cooperation (APEC) member economies. To connect itself with Western Europe, Japan has also implemented two major FTAs, including the Japan-EU Economic Partnership Agreement (EPA). That became effective in February 2019, and the Japan-UK Comprehensive Economic Partnership Agreement (CEPA), which came into force in January 2021. Japan's aim has consistently been to achieve high-standard, WTO-consistent FTAs.

The G20 leaders also declared that the cross-border flow of data, information, ideas, and knowledge would stimulate productivity, innovation, and sustainable development, and recommended "data free flow with trust" (DFFT), recognizing the challenges of protecting privacy, data, intellectual property rights (IPR), and security. This concept reflected the Osaka Track, which Japan promoted as one of the priorities set for the summit to encourage collective efforts to realize governance of global data flows and unleash the benefits of cross-border flows of trusted data. The "free" part of DFFT does not mean a world without appropriate rules or safeguards, but it meant a world where the security of data flows and IPR protection are ensured to avoid damaging public trust in digital technologies and data management. So "trust" is crucial and designed to coexist with freedom (or openness) in symbiosis. ${ }^{13}$ It should be noted that the e-commerce chapter of the CPTPP is consistent with the DFFT concept, while close to 90 WTO members have also been pursuing new negotiations on rule-making for digital trade or e-commerce.

\footnotetext{
${ }^{12}$ See G20 Osaka Leaders' Declaration, June 2019. G20 Osaka Leaders' Declaration I Documents and Materials I G20 Osaka Summit 2019 (mofa.go.jp).

${ }^{13}$ See World Economic Forum, Data Free Flow with Trust (DFFT): Paths toward Free and Trusted Data Flow, White Paper (May 2020). hhttp://www3.weforum.org/docs/WEF_Paths_Towards_F ree_and_Trusted_Data\%20_Flows_2020.pdf.
} 
The leaders also endorsed the "G20 Principles for Quality Infrastructure Investment," which was recognized as a common strategic direction and high-level goal. Japan has been promoting the concept of "quality infrastructure investment" for some time and in May 2015 issued a document titled Partnership for Quality Infrastructure, and pushed forward the "G7 Ise-Shima Principles for Promoting Quality Infrastructure" at the Ise-Shima G7 summit hosted by Japan in May 2016. ${ }^{14}$

The G20 principles adopted in Osaka are a streamlined version of the previous ones and describe a set of voluntary, non-binding principles that include maximizing the positive impact of infrastructure to achieve sustainable growth and development (job creation, transfer of expertise, enhancing connectivity); raising economic efficiency in view of life-cycle cost; integrating environmental considerations into infrastructure investments; building resilience against natural disasters and other risks; integrating social considerations in infrastructure investment (open access to infrastructure services, safety, respect for gender, and the socially vulnerable); and strengthening infrastructure governance (openness and transparency of procurement, and debt sustainability).

\subsection{Support for the Bretton Woods System and WTO Reform}

Japan is a staunch supporter of the IMF and the World Bank as their number two shareholder. Following the GFC, Japan provided USD 100 billion to the IMF, which had only USD 200 billion available for lending at the time, and encouraged other member countries to provide similar funding. In response to the COVID-19 pandemic in April 2020, Japan provided an additional USD 100 million to the IMF's CCRT (Catastrophe Containment and Relief Trust) as immediately available resources to support grant-based debt service relief for the poorest and most vulnerable countries, and also announced it would double its contribution to the poverty reduction and growth trust from the existing SDR 3.6 billion, with an additional SDR 1.8 billion immediately available and a subsequent SDR 1.8 billion to be provided once other member countries made their contributions.

While supporting the IMF and the World Bank, Japan has taken leadership in developing regional arrangements, such as the Asian Development Bank (ADB) to provide regional public goods as well as the Chiang Mai Initiative Multilateralization (CMIM) and the ASEAN+3 Macroeconomic Research Office (AMRO) to promote regional financial stability. The creation and management of CMIM and AMRO were made possible by working with other East Asian countries, particularly China. If the World Bank does not provide sufficient financial resources for Asia's development needs, Japan can increase its assistance bilaterally and multilaterally through the

\footnotetext{
${ }^{14}$ The G7 principles focused on: life-cycle cost including maintenance, repair and management; social and environmental consideration; local job creation, technology transfer, and human resource development; consistency with the borrowing country's development strategy and effective resource mobilization.
} 
ADB. If the IMF does not respond to the needs of Asian countries in the case of a liquidity shortage, Japan is also willing to extend liquidity support through bilateral currency swaps and via the CMIM financial safety net supported by AMRO's surveillance services.

Japan is an active defender of the WTO and works with the US, EU, and other likeminded countries on WTO reform to introduce and/or strengthen disciplines on the protection of IPR and the avoidance of "non-market" policies and practices, improve notification and transparency obligations, clarify "developing country" status, and restore an effective dispute settlement mechanism.

Among the WTO reform agendas, the most urgent priority would be to restore an effectively functioning $\mathrm{AB}$ for dispute settlement. For this, the US and the EU have to reconcile their differences in the dispute settlement system. ${ }^{15}$ Japan's view of dispute settlement embraces that of the US, considering its negative experience with disputes with the Republic of Korea regarding the latter's import ban on fishery products introduced after the Great East Japan Earthquake, tsunami, and nuclear power plant accidents, while also recognizing the importance of accumulating a set of effective rules through the WTO's "court." Being more flexible, Japan can make efforts, together with the Ottawa Group, ${ }^{16}$ to narrow the gap between the US and the EU.

It will be more difficult for WTO members to come to consensus agreements on other contentious issues, such as new trade disciplines on "non-market" policies and practices; notification and transparency obligations; "developing country" status; and S\&D treatment.

Given the wide division between developed and developing members, not just between the US and China, a long-term approach is advised to narrow the gap between the two. To tackle these issues, Japan, together with the US and the EU, should hold an intensive dialogue with China to narrow these differences. On the issue of "nonmarket" policies and practices, the two sides should focus on the fundamental role of the WTO, namely whether and how the institution should promote market-based economic practices, openness, and competition through reducing members' anticompetitive policies and practices (including "non-market" ones such as state subsidies and SOEs). On the issues of notification obligations and "developing country" status, they should discuss the importance of S\&D treatment for countries truly in need of it and in justifiable areas as well as the role of capacity development programs to support developing countries, particularly low-income ones, in implementing agreed notification and transparency obligations.

Given the current constrained role of the WTO, Japan has been engaged in negotiations for plurilateral agreements. These are an important tool for liberalization

\footnotetext{
${ }^{15}$ A draft decision paper circulated at the WTO by Ambassador David Walker of New Zealand, who was the Facilitator of the Informal Process on Matters related to the Functioning of the Appellate Body, in November 2019, WT/GC/W/791, was a good starting point for agreement but was reportedly rejected by the US delegation. https://docs.wto.org/dol2fe/Pages/SS/directdoc.aspx? filename $=\mathrm{q}: / \mathrm{WT} / \mathrm{GC} / \mathrm{W} 791$. pdf\&Open $=$ True.

${ }^{16} \mathrm{https}: / /$ www.canada.ca/en/global-affairs/news/2019/05/ottawa-group-and-wto-reform.html.
} 
and rule-making among like-minded members, given the requirement of consensusbased decision-making at the WTO and the difficulties of "single undertaking" principles that failed during DDR negotiations. Plurilateral agreements allow a group of WTO members to address specific issues and areas on a MFN (Most Favoured Nation) basis, benefiting non-signatories as well. This lays the foundation for WTOwide rule-making in the future, thereby supporting a multilateral trading system. These include the Agreement of Government Procurement (GPA; 1981, revised in 1996, further revised in 2012, and applied to all WTO members in 2021); the Information Technology Agreement (ITA; 1997, expanded in 2014); the Environmental Goods Agreement (EGA — to be concluded); the Trade in Services Agreement (TiSA - to be concluded) and more recently an agreement on e-commerce (under negotiation).

\subsection{Cooperation-Japan and China}

Given the expanding market size of China and deep economic interdependence through trade and investment, it is in Japan's interest to cooperate with China in mutually beneficial areas, even in the era of US-China strategic competition. Japan's approach has been to balance security and economic interests and encourage China to transform itself into an internationally harmonious, open market economy so that it becomes, and acts as, a responsible global player. Key instruments to achieve these aims are high-standard FTA negotiations, high-quality infrastructure cooperation in third-party countries, and bilateral and regional financial cooperation.

First, while Japan would welcome the US to return to TPP, Japan also welcomes President Xi Jinping's indication that China is seriously considering participation in CPTPP. The reason is that Japan wants to see China's shift from "state capitalism" to a "market-oriented" economy through trade and investment reforms and associated changes in domestic legal and regulatory systems. This would enable China to return to "reform and opening up," redefine the role of government consistent with an open market economy, substantially reduce subsidies for "Made-in-China 2025," and restructure and ultimately privatize SOEs and state-owned commercial banks.

However, joining CPTPP is a significant challenge for China and would require much greater IPR protection; further opening of the services sector; a more open internet; much freer flows of data across borders than RCEP ; addressing the distortion of market competition created by SOEs and government subsidies. Most significantly, the chapter on SOEs would require China to share information on its SOEs and expressly restrict preferential treatment for them. The Japanese government does not seem to have a clear strategy of how to encourage China to carry out domestic reforms to prepare for CPTPP negotiations, but a useful avenue would be to build on RCEP agreements and pursue negotiations for a high-standard China-Japan-ROK (CJK) FTA, which would address provisions included in CPTPP. If China makes efforts to agree on a high-standard CJK FTA, the country would be in the position to move to formal discussions for CPTPP participation. 
Second, there is scope for greater cooperation between Japan and China to support high-quality infrastructure development and connectivity in third countries. If the two countries were to agree to pursue joint projects in third countries by their firms under the four conditions of economic viability, openness, transparency, and fiscal sustainability, this would create synergies in supporting developing countries in need of infrastructure investment. ${ }^{17}$

The BRI has been useful in augmenting infrastructure investment and connectivity for many developing countries. But at the same time the BRI has encountered various international criticisms in recent years, such as non-transparency of project details and procurements; disregard for borrowing countries' economic, environmental, and social interests; lack of considerations for economic feasibility and debt sustainability, etc. Partly as a response, in the "2nd BRI Forum for International Cooperation" (April 2019), President Xi Jinping underlined the need for developing high-quality BRI projects, stressing transparency, clean governance, green projects, widely accepted rules and standards, and commercial and fiscal sustainability. In addition, China agreed to the "G20 Principles of Quality Infrastructure Investment" adopted at the G20 Osaka Summit (June 2019). Thus, Japan-China cooperation in third-party countries for high-quality projects can help China to enhance the quality of BRI projects. This will contribute to the convergence between the BRI and the economic pillar of the FOIP (Free and Open Info-Pacific) vision. ${ }^{18}$

Although not an AIIB (Asian Infrastructure Investment Bank) member, Japan together with the US has encouraged the World Bank, ADB and other existing multilateral development banks to work with AIIB. The aim has been to enable AIIB to follow international standards on environmental and social safeguards, avoid economically non-viable projects, and maintain debt sustainability in borrowing countries. Partly as a result, AIIB has been performing better than initially expected as it has avoided projects with low environmental and social standards and potential debt distress.

\footnotetext{
${ }^{17}$ There are similarities and differences between Japan's and China's approaches to development assistance. Japan's assistance has been focusing on the trinity combination of ODA for infrastructure development, trade expansion and foreign direct investment (FDI) inflows, thereby supporting recipient countries' industrialization and economic development. China also supports recipient countries' economic development through infrastructure investment. One of the major differences between the two countries' approaches is that Japan has provided grants and technical assistance to support low-income countries and yen-loans to support middle-income countries because of debt sustainability concerns, while China provides loans even for low-income countries which may lack loan repayment capacities.

${ }^{18}$ Japan's FOIP vision is now shared by the US, Australia, India, and ASEAN and has attracted the interests of the UK and the EU. The FOIP vision includes both security and economic pillars. The economic pillar includes trade and investment as well as infrastructure connectivity. The RCEP and CPTPP are key arrangements for trade and investment, and participation by India and the US in the respective arrangements would strengthen the initiative. High-quality infrastructure connectivity in transport, energy, and digital sectors, guided by the "G20 Principles for Quality Infrastructure Investment," is another element. It is designed to be inclusive and open to any country sharing the vision and thus does not exclude China.
} 
In addition, as the two largest official bilateral creditors to these low- and lower middle-income countries, Japan's and China's participation in the G20 DSSI (Debt Service Suspension Fund) has been useful in assisting indebted countries affected by COVID-19 to alleviate their fiscal constraints.

Third, Japan and China have been pursuing bilateral and regional financial cooperation. Bilateral financial cooperation (agreed to in October 2018) includes China's provision of CNY 200 billion Renminbi Qualified Foreign Institutional Investor (RQFII) status for Japanese investors; China's setting up of an RMB clearing bank in Tokyo; an arrangement of bilateral yen-yuan currency swaps; China's issuance of licenses to Japanese financial firms to conduct securities businesses in China; and mutual listing of exchange-traded funds (ETFs) in the respective markets. Other types of bilateral financial cooperation include the use of yen and yuan for trade, finance, and reserve holdings, issuance of RMB bonds in Tokyo, and making yen-yuan direct exchange active in their foreign exchange markets.

More importantly, the two countries have been cooperating to promote regional financial stability in East Asia: creating CMIM for ASEAN + 3 economies, supplemented by bilateral currency swap arrangements, to prepare for a financial crisis or the risk of such a crisis; establishing AMRO for effective regional economic surveillance; and participating in IMF programs in other countries, an example being Mongolia, where China, Japan, and the ROK jointly provided financial assistance. One remarkable fact is that Japan-China regional financial cooperation remained intact even at the height of extreme bilateral tension in 2012-13 when Japan nationalized the Senkaku Islands, which set off large-scale anti-Japan demonstrations in various cities in China and the suspension of official bilateral dialogues and cooperation programs.

\section{Conclusion}

The current global structural shift, which is characterized by the relative decline of the US and other advanced economies, and the rapid rise of the Chinese and other emerging and developing economies, will continue in the decades to come. This means that global economic governance must accommodate such a structural shift if it is to be sustained over the long term.

Even though China is projected to become the number one economy in the world in around 2030, the US can still preserve its global leadership and security by closely coordinating with the EU, Japan, and other like-minded democracies. By uniting democracies and retaining a rules-based liberal economic order, the US would be able to deter China's ambition (if any) to challenge and replace it as the next global hegemon. Thus, the return of the US to multilateralism and international cooperation is essential to global peace and stability. This will allow the US and its allies to craft a strategy of how to get China and other emerging and developing economies engaged more deeply in the existing international order. Their challenge is to design a framework to accommodate the global structural shift, allow the coexistence of 
different systems, and induce convergence toward a rules-based market economy, openness, and transparency.

Japan can play a major role in addressing such challenges. Its tasks include retaining a rules-based, liberal, multilateral economic order; making global forums (such as the G7 and G20) and Bretton Woods Systems more effective; and engaging China so it becomes a responsible global player. Japan needs to work with not only the US and the EU, but also China and other major emerging economies, to reform the WTO and put it back on the center stage of global rule-making in twenty-first-century trade and investment.

At the same time, Japan has been developing regional arrangements in a way consistent with global precedent, implementing high-standard FTAs, such as the CPTPP, Japan-EU EPA, and Japan-UK CEPA, which help to preserve a liberal trading system given the constrained role of the WTO today. Japan's approach of promoting the FOIP vision and encouraging domestic and external reforms in China through a high-quality BRI and a high-standard CJK FTA would also contribute to stronger global economic governance. Lastly, the return of the US to TPP and China's participation in CPTPP would ultimately prove to be a big plus in strengthening global economic governance.

\section{References}

US National Security Council (2020)United States Strategic Approach to the People's Republic of China. https://www.whitehouse.gov/wp-content/uploads/2020/05/US-Strategic-Approach-toThe-Peoples-Republic-of-China-Report-5.20.20.pdf.

VanGrassteck C (2013) The history and future of the world trade organization. WTO Publications, Geneva. www.wto.org/english/res_e/booksp_e/historywto_e.pdf

Willems C (2020) Revitalizing the world trade organization. Atlantic Council, Washington, DC. https://www.atlanticcouncil.org/wp-content/uploads/2020/11/Revitalizing-the-WTO-Report_ Version-11.6.pdf

Masahiro Kawai is the Representative Director of the Economic Research Institute for Northeast Asia (ERINA) in Niigata, Japan. He teaches Asian finance at the University of Tokyo as Professor Emeritus; he also serves as a Councilor of the Bank of Japan; a Senior Fellow of the Policy Research Institute of Japan's Finance Ministry and he is a distinguished Research Fellow of the Japan Forum on International Relations. Previously, Dr. Kawai held positions as Dean of the Asian Development Bank (ADB) Institute and Chief Economist for the World Bank's East Asia and the Pacific Region. He holds a BA in economics from the University of Tokyo and a Ph.D. in economics from Stanford University. 
Open Access This chapter is licensed under the terms of the Creative Commons AttributionNonCommercial-NoDerivatives 4.0 International License (http://creativecommons.org/licenses/bync-nd/4.0/), which permits any noncommercial use, sharing, distribution and reproduction in any medium or format, as long as you give appropriate credit to the original author(s) and the source, provide a link to the Creative Commons license and indicate if you modified the licensed material. You do not have permission under this license to share adapted material derived from this chapter or parts of it.

The images or other third party material in this chapter are included in the chapter's Creative Commons license, unless indicated otherwise in a credit line to the material. If material is not included in the chapter's Creative Commons license and your intended use is not permitted by statutory regulation or exceeds the permitted use, you will need to obtain permission directly from the copyright holder.

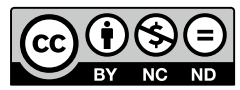

